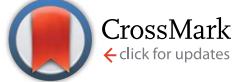

Cite this: RSC Adv., 2016, 6, 39636

Received 10th March 2016

Accepted 13th April 2016

DOI: $10.1039 / c 6 r a 06403 e$

www.rsc.org/advances

\section{A ruthenium derivative of quercetin with enhanced cholesterol-lowering activity}

\author{
M. Cuccioloni, ${ }^{\star a}$ L. Bonfili, ${ }^{a}$ M. Mozzicafreddo, ${ }^{a}$ V. Cecarini, ${ }^{a}$ R. Pettinari, ${ }^{b}$ \\ F. Condello, ${ }^{b}$ C. Pettinari, ${ }^{b}$ F. Marchetti, ${ }^{c}$ M. Angeletti ${ }^{a}$ and A. M. Eleuteri ${ }^{a}$
}

\begin{abstract}
A ruthenium(II) $p$-cymene derivative of quercetin was synthesized and functionally tested for cholesterollowering ability via direct 3-hydroxy-3-methyl-glutaryl-CoA reductase (HMGR) inhibition. Ruthenium complexation dramatically increased the inhibition potency of the parent quercetin toward HMGR, with a consequent enhancement of the cholesterol-lowering effect in hepatic cells.
\end{abstract}

\section{Introduction}

Natural polyphenols are an important part of the human diet, and their routine consumption has been associated with a lower risk of developing pathological conditions, among these cancer $^{\mathbf{1 , 2}}$ and cardiovascular disorders. ${ }^{3}$ Specifically, these molecules exert a broad range of biological activities, which have been reported to regulate $\mathrm{ROS},{ }^{4}$ cell proliferation, ${ }^{5}$ apoptosis, ${ }^{6}$ angiogenesis, ${ }^{7}$ and cholesterol homeostasis. ${ }^{\mathbf{8} 9}$ In particular, some polyphenols have been shown to exert their cholesterol-lowering action by directly blocking the activity of 3-hydroxy-3-methyglutaryl coenzyme A reductase (HMGR), ${ }^{\mathbf{1 0}}$ an endoplasmic reticulum-bound enzyme that rate-regulates early stages of cholesterol biosynthesis, thus representing a possible non-toxic alternative to statin-based treatments ${ }^{11,12}$ in non-life threatening conditions, as confirmed by studies on regular vegetables (and/or vegetable derivatives) consumers. $^{\mathbf{1 3}}$ Herein, in the light of the promising evidences supporting the use of metals in the potentiation of bioactive compounds, ${ }^{\mathbf{1 4 , 1 5}}$ we synthesized a ruthenium(II) $p$-cymene derivative of quercetin, one of the most abundant polyphenol in human diet, and we tested its ability to decrease cholesterol levels via HMG-CoA reductase inhibition according to a concerted approach based on computational, cell-free and cell-based studies.

\section{Results and discussion}

\section{Synthesis of [( $p$-cymene $) \mathrm{Ru}(\mathrm{que}) \mathrm{Cl}]$}

A methanol solution ( $5 \mathrm{~mL}$ ) of $\mathrm{KOH}$ ( $9 \mathrm{mg}, 0.165 \mathrm{mmol}$ ) was added to quercetin (queH, $50 \mathrm{mg}, 0.165 \mathrm{mmol}$ ) dissolved in acetonitrile $(20 \mathrm{~mL})$. The mixture was stirred for $30 \mathrm{~min}$ at room temperature in inert $\mathrm{N}_{2}$ atmosphere and then $\left[\mathrm{Ru}(p \text {-cym }) \mathrm{Cl}_{2}\right]_{2}(50 \mathrm{mg}, 0.0825$ $\mathrm{mmol}$ ) was added. The resulting solution was stirred at room

${ }^{a}$ School of Biosciences and Veterinary Medicine, University of Camerino, Via Gentile III da Varano, 62032 Camerino, MC, Italy.E-mail: massimiliano.cuccioloni@unicam.it ${ }^{b}$ School of Pharmacy, University of Camerino, Italy ${ }^{c}$ School of Science and Technology, University of Camerino, Italy temperature for $1 \mathrm{~h}$. The solvent was removed under reduced pressure, dichloromethane $(10 \mathrm{~mL})$ was added and the mixture was filtered to remove potassium chloride. $N$-Hexane $(10 \mathrm{~mL})$ was added and upon solvent removal, the brown precipitate was analysed and shown to be the title compound (32 $\mathrm{mg}, 0.055 \mathrm{mmol}$, yield 33\%). It is soluble in DMSO, alcohols, acetone, acetonitrile and slightly soluble in chlorinated solvents. Mp 168-170 ${ }^{\circ} \mathrm{C}$. Anal. calcd for $\mathrm{C}_{25} \mathrm{H}_{24} \mathrm{ClO}_{7} \mathrm{Ru}$ : C, 52.40; H, 4.22. Found: C, 52.21; H, 4.12. IR $\left(\mathrm{cm}^{-1}\right): 3275 \mathrm{br}, 2960 \mathrm{~m} \nu\left(\mathrm{C}_{\text {arom-H }}\right), 1645 \mathrm{~m}, 1603 \mathrm{~s} \nu(\mathrm{C}=\mathrm{O}), 1510 \mathrm{~s}$ $\nu(\mathrm{C}=\mathrm{C}), 1427 \mathrm{~m}, 1360 \mathrm{~s}, 1315 \mathrm{~s}, 1247 \mathrm{~s}, 1200 \mathrm{~s}, 1171 \mathrm{vs}, 1091 \mathrm{~m}$, $1055 \mathrm{~m}, 999 \mathrm{~m}, 931 \mathrm{~m}, 877 \mathrm{~m}, 788 \mathrm{~m}, 704 \mathrm{~m}, 689 \mathrm{~m} .{ }^{1} \mathrm{H} \mathrm{NMR}\left(\mathrm{CD}_{3} \mathrm{OD}\right.$, $298 \mathrm{~K}): \delta, 1.29$ (d, 6H, $\left.\mathrm{CH}_{3} \mathrm{C}_{6} \mathrm{H}_{4} \mathrm{CH}\left(\mathrm{CH}_{3}\right)_{2}\right), 2.19\left(\mathrm{~s}, 3 \mathrm{H}, \mathrm{CH}_{3} \mathrm{C}_{6} \mathrm{H}_{4}-\right.$ $\left.\mathrm{CH}\left(\mathrm{CH}_{3}\right)_{2}\right), 2.78\left(\mathrm{~m}, 1 \mathrm{H}, \mathrm{CH}_{3} \mathrm{C}_{6} \mathrm{H}_{4} \mathrm{CH}\left(\mathrm{CH}_{3}\right)_{2}\right), 5.64 \mathrm{~d}, 5.87 \mathrm{~d}(4 \mathrm{H}$, $\left.\mathrm{CH}_{3} \mathrm{C}_{6} \mathrm{H}_{4} \mathrm{CH}\left(\mathrm{CH}_{3}\right)_{2}\right), 6.17$ (s, $1 \mathrm{H}, \mathrm{C}(6) H$ of que), $6.38(\mathrm{~s}, 1 \mathrm{H}, \mathrm{C}(8) H$ of que), 6.88 (d, $1 \mathrm{H}, \mathrm{C}\left(5^{\prime}\right) H$ of que), $7.62\left(\mathrm{~d}, 1 \mathrm{H}, \mathrm{C}\left(6^{\prime}\right) H\right.$ of que), 7.73 (s, $1 \mathrm{H}, \mathrm{C}\left(2^{\prime}\right) H$ of que). ${ }^{13} \mathrm{C} \mathrm{NMR}$ (DMSO, $\left.298 \mathrm{~K}\right): \delta, 18.5\left(\mathrm{~s}, \mathrm{CH}_{3^{-}}\right.$ $\left.\mathrm{C}_{6} \mathrm{H}_{4} \mathrm{CH}\left(\mathrm{CH}_{3}\right)_{2}\right), 22.2\left(\mathrm{~s}, \mathrm{CH}_{3} \mathrm{C}_{6} \mathrm{H}_{4} \mathrm{CH}\left(\mathrm{CH}_{3}\right)_{2}\right), 30.6\left(\mathrm{~s}, \mathrm{CH}_{3} \mathrm{C}_{6} \mathrm{H}_{4}\right.$ $\left.\mathrm{CH}\left(\mathrm{CH}_{3}\right)_{2}\right)$, 86.2, 87.1, 100.7, $107.0\left(\mathrm{~s}, \mathrm{CH}_{3} C_{6} \mathrm{H}_{4} \mathrm{CH}\left(\mathrm{CH}_{3}\right)_{2}\right), 94.0$ (s, $C(8)$ of que), 98.8 (s, $C(6)$ of que), 103.6 (s, $C(10)$ of que), 115.7 (s, $C\left(2^{\prime}\right)$ of que), 116.2 (s, $C\left(5^{\prime}\right)$ of que), 120.6 (s, $C\left(6^{\prime}\right)$ of que), 122.6 (s, $C\left(1^{\prime}\right)$ of que), 136.4 (s, $C(3)$ of que), 145.7 (s, $C\left(3^{\prime}\right)$ of que), 147.4 (s, $C(2)$ of que), 148.3 (s, $C\left(4^{\prime}\right)$ of que), 156.8 (s, $C(9)$ of que), 161.4 (s, $C(5)$ of que), 164.5 (s, $C(7)$ of que), 176.5 (s, $C(4)$ of que). ESI-MS(+) $\mathrm{CH}_{3} \mathrm{OH}(\mathrm{m} / \mathrm{z} \text {, relative intensity\%): } 537 \text { [100] [(p-cymene) } \mathrm{Ru}(q u e)]^{+}$, $573[70]\left[\mathrm{Na}((p \text {-cymene }) \mathrm{Ru}(\mathrm{que}))_{2}(\mu-\mathrm{OH})\left(\mathrm{CH}_{3} \mathrm{OH}\right)\right]^{2+}$.

Finally, [(p-cymene)Ru(que)] (Fig. 1) was isolated by RP-HPLC.

\section{Molecular docking study}

Computational analyses were performed using Autodock Vina software. ${ }^{16}$ Docking studies on the X-ray crystal structure of the human HMGR predicted potential differences in the binding behaviour between Que/HMGR and Ru-Que/HMGR both in terms of interaction strength and binding geometry. Specifically, quercetin was calculated to selectively target the cofactor-binding portion of the catalytic site of the reductase (Fig. 2).

Conversely, Ru-Que accommodated within the substrate cleft with the $p$-cymene ring pointing outside of the active site. 


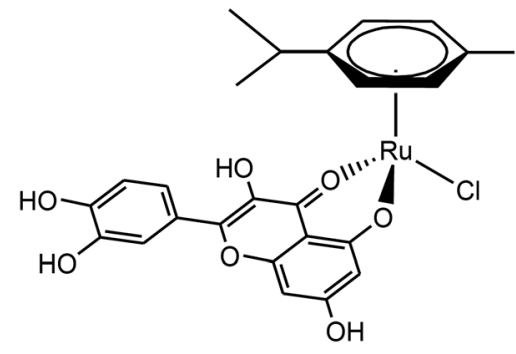

Fig. 1 Chemical structure of $[(p-c y m) R u(q u e) C l]$ derivative.

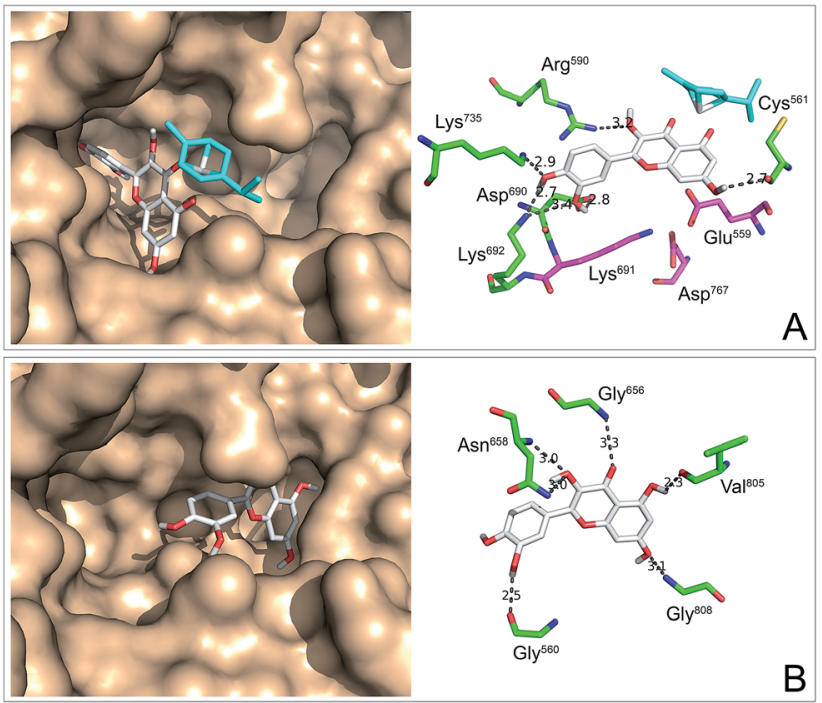

Fig. 2 Molecular docking of Ru-Que (Box A) and Que (Box B) within the catalytic region of $\mathrm{HMG}-\mathrm{COA}$ reductase. Surface, and cartoon and stick representations with $\mathrm{H}$-bonds formed are shown in left and right panels, respectively. Carbon atoms of catalytic residues are highlighted in pink.

Table 1 Energy contributions to total free energy of binding (kcal $\mathrm{mol}^{-1}$ )

\begin{tabular}{llllll}
\hline & Gauss 1 & Gauss 2 & Repulsion & Hydrophobic & Hydrogen \\
\hline Quercetin & 82.67 & 1101.73 & 2.82 & 8.41 & 5.22 \\
Ru-Que & 75.67 & 1409.18 & 3.39 & 19.71 & 4.60
\end{tabular}

According to this predictive model, the polyphenol and the arene part of the derivative were in close proximity of $\mathrm{Glu}^{559}$, $\mathrm{Lys}^{691}$, and $\mathrm{Asp}^{767}$, three of the catalytic residues involved in substrate recognition ${ }^{17}$ (Fig. 2, panel A). Additionally, a nearly 3-fold increase in binding affinity was predicted for Ru-Que $\left(K_{\mathrm{D}, \mathrm{Ru}-\mathrm{Que}, \mathrm{p}}=0.49 \mu \mathrm{M}\right)$, with respect to quercetin $\left(K_{\mathrm{D}, \text { Que, }}=1.3 \mu \mathrm{M}\right)$. The analysis of energy components (Table 1), revealed a major contribution of the steric interactions (with higher Gauss contribution) and of the hydrophobic interaction in the higher stability of Ru-Que/HMGR complex.

\section{SPR binding study}

A comparative analysis of the kinetics of the binding between quercetin and Ru-Que to human HMGR was performed on an
A
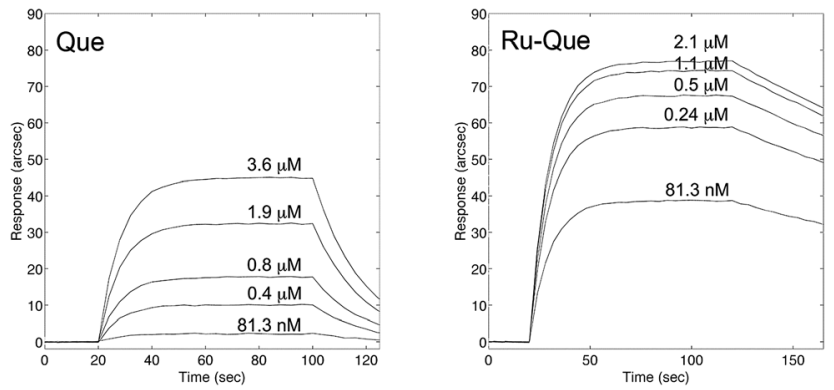

Fig. 3 Representative overlay of association and dissociation kinetics of soluble Que (Box A) and Ru-Que (Box B) to surface-bound HMGCoA reductase.

optical biosensor. HMGR was surface anchored as described in the methods section to an optimal surface density that minimized possible hindering effects during recognition events. Next, either quercetin or Ru-Que was added at increasing concentrations in the range $81 \mathrm{nM}-3.6 \mu \mathrm{M}$ and $81 \mathrm{nM}-2.1 \mu \mathrm{M}$, respectively. Kinetic raw data were globally-fit to standard single- and doubleexponential binding models as previously reported (Fig. 3). ${ }^{18}$

Monophasic kinetics were always observed upon the addition of both soluble compounds (the biphasic model was always statistically non-significant at $95 \%$ confidence as checked by a standard $F$-test procedure). This experimental approach confirmed the predicted increase in the binding affinity for HMGR of quercetin upon ruthenium complexation $\left(K_{\mathrm{D}, \mathrm{Q}}=\right.$ $\left.[2.85 \pm 0.26] \mu \mathrm{M}, K_{\mathrm{D}, \mathrm{RuQ}}=[91 \pm 19] \mathrm{nM}\right)$, with association $\left(k_{\mathrm{ass}, \mathrm{Q}}\right.$ $\left.=[19000 \pm 2000] \mathrm{M}^{-1} \mathrm{~s}^{-1} ; k_{\text {ass, RuQ }}=[46000 \pm 9000] \mathrm{M}^{-1} \mathrm{~s}^{-1}\right)$, and more evidently dissociation events $\left(k_{\text {diss, },}=[0.0541 \pm\right.$ $\left.0.005] \mathrm{s}^{-1} ; k_{\mathrm{diss}, \mathrm{RuQ}}=[0.0041 \pm 0.0009] \mathrm{s}^{-1}\right)$ significantly contributing to enhance the stability of the complex.

Additionally, in line with computational predictions the presaturation of HMGR layer with either HMG-CoA or NADPH prevented the binding of Ru-Que and quercetin, respectively.

\section{Inhibition study}

The modulatory effect of quercetin and Ru-Que on HMGR was evaluated by measuring the enzymatic activity of both isolated and microsomal HMGR from human liver carcinoma HepG2 cells according to a chromatography-based method. ${ }^{19}$ In detail, the enzymatic residual activity was monitored upon $60 \mathrm{~min}$ preincubation of the HMGR with increasing levels of Que (0-2 $\mathrm{mM}$ ), Ru-Que (0-0.5 mM), pravastatin $(0-5 \mu \mathrm{M})$ and simvastatin $(0-100 \mu \mathrm{M})$.

The pre-formed enzyme-inhibitor complex was added to 1.55 $\mu \mathrm{M}$ HMG-CoA and $2.68 \mathrm{mM}$ NADPH dissolved in the activity buffer (100 mM phosphate, $1 \mathrm{mM}$ EDTA, $10 \mathrm{mM}$ DTT, and $2 \%$ DMSO at pH 6.8), and stored for $60 \mathrm{~min}$ at $37^{\circ} \mathrm{C}$. The resulting mixture was separated by RP-HPLC. Residual activities, expressed as the ratio of mevalonate levels in the presence and in the absence of a given inhibitor concentration, were derived from raw data using a standard model for reversible competitive inhibition. ${ }^{20}$ Hydrophilic pravastatin and hydrophobic simvastatin were used as reference inhibitors of HMGR. 

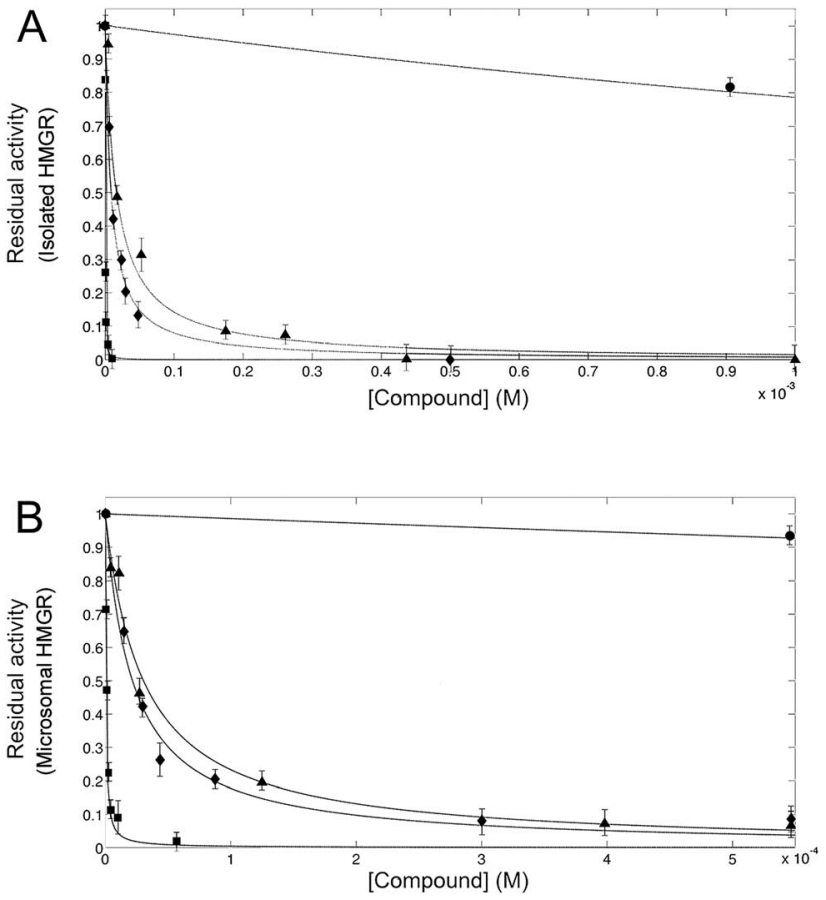

Fig. 4 Residual activity plot of isolated (Box A) and microsomal HMGR (Box B) in the presence of quercetin (-), Ru-Quercetin ( $\mathbf{\Delta})$, simvastatin ( ) and pravastatin ( $\boldsymbol{\square})$. Raw data for the HMGR inhibition were fitted to eqn (1).

Table 2 Experimentally obtained $K_{\mathrm{i}}$ values for isolated and microsomal HMGR activity calculated from the fit of raw data to eqn (1)

\begin{tabular}{lll}
\hline & $K_{\mathrm{i}, \text { isolated }}(\mathrm{M})$ & $K_{\mathrm{i}, \text { microsomal }}(\mathrm{M})$ \\
\hline Quercetin & $(2.03 \pm 0.21) \times 10^{-5}$ & $(3.88 \pm 1.32) \times 10^{-5}$ \\
Ru-Que & $(9.23 \pm 1.13) \times 10^{-8}$ & $(1.69 \pm 0.33) \times 10^{-7}$ \\
Pravastatin & $(5.90 \pm 2.18) \times 10^{-10}$ & $(8.43 \pm 0.98) \times 10^{-9}$ \\
Simvastatin & $(4.82 \pm 1.65) \times 10^{-8}$ & $(1.28 \pm 0.54) \times 10^{-7}$
\end{tabular}

Isolated HMGR activity was clearly dependent on each treatment, as shown in Fig. 4, panel A. The superimposition of inhibitions curves and the comparison of inhibition constants showed that the complexation with ruthenium induced a nearly 200 -fold increase in the inhibition potency of Que (Table 2). The observed inhibitory potency was retained also against microsomal HMGR from HepG2 cells (Fig. 4, panel B), although to a generally lower extent with respect to cell-free assay. With respect to $K_{\mathrm{i}}$ values obtained from the analysis on isolated enzymes, minor changes were observed (Table 2), but the overall inhibition trend was maintained (again, Ru-complexation enhanced quercetin inhibitory potency by more than 200 -fold).

\section{Effect on cholesterol levels}

Finally, cytoplasmic cholesterol levels in HepG2 cells upon treatment were measured to assess the effective cholesterol-lowering capacity of Ru-Que, in comparison with both the parent

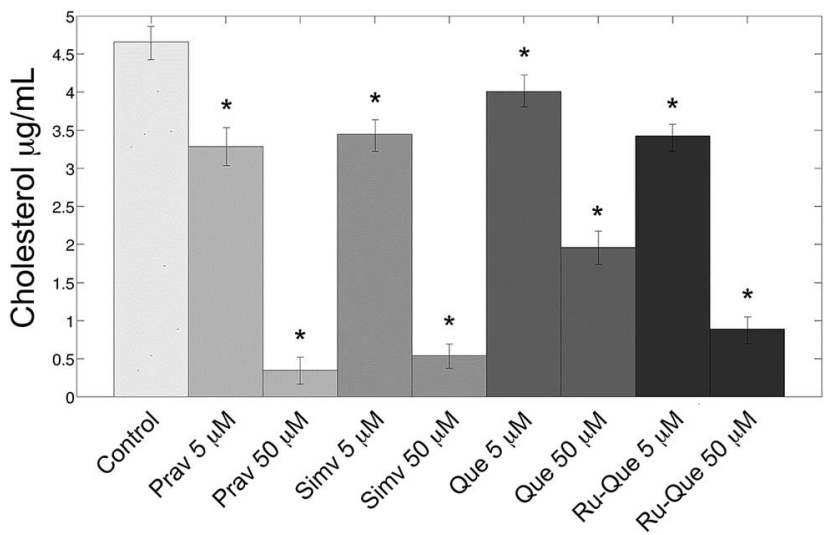

Fig. 5 Cholesterol cytoplasmic concentration upon $4 \mathrm{~h}$ treatment with 5-50 $\mu \mathrm{M}$ Que, Ru-Que, simvastatin and pravastatin.

compound and two commercial statins. After $4 \mathrm{~h}$ incubation at 37 ${ }^{\circ} \mathrm{C}$ in the presence of 5 and $50 \mu \mathrm{M}$ of each compound, cytoplasmic cholesterol concentration was measured using AmplexRed Cholesterol Assay kit. After $4 \mathrm{~h}$, fluorescence measurements were recorded $\left(\lambda_{\mathrm{exc}}=540 \mathrm{~nm}, \lambda_{\mathrm{em}}=590 \mathrm{~nm}\right)$.

Our results indicated a dose-dependent diminution of cytoplasmic cholesterol for all four tested compounds (Fig. 5). Remarkably, Ru-Que showed a cholesterol cytoplasmic lowering ability significantly higher than the parent compound and comparable to those observed for both pravastatin and (in particular) simvastatin.

\section{Evaluation of cytotoxicity}

Interestingly, Ru-Que had a negligible cytotoxicity (lower than Que) on HepG2 cells in the range of concentration tested in the cholesterol assay, the only significant effect being evident at $100 \mu \mathrm{M}$ (Fig. 6).

Most importantly, simvastatin, which is known to induce more evident side effects, showed higher toxicity with respect to Ru-Que (remanding to its use as potential anticancer agent), although presenting similar cholesterol-lowering potency.

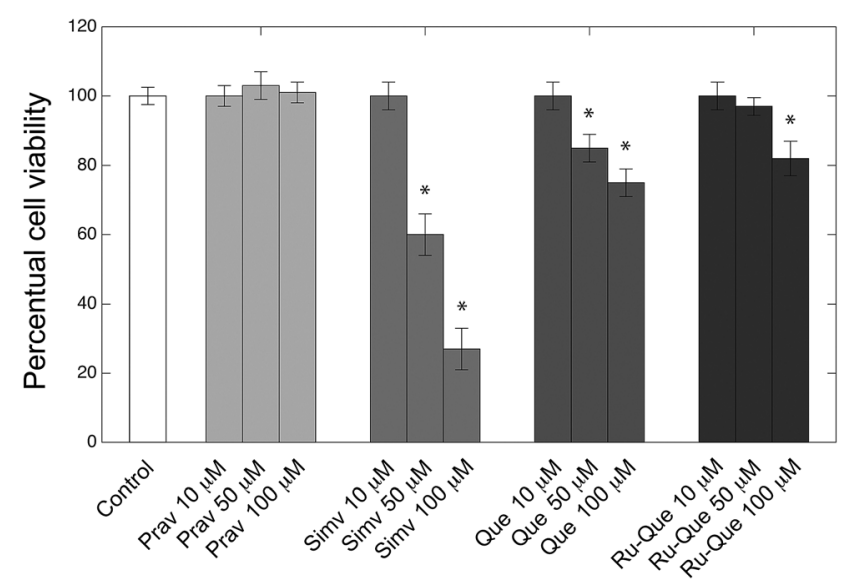

Fig. 6 Results of MTT viability assay on HepG2 after treatment with 0$100 \mu \mathrm{M}$ of Que, Ru-Que, simvastatin and pravastatin for $24 \mathrm{~h}$. 


\section{Experimental}

\section{Materials}

Carboxylate cuvettes, ethanolamine, 1-ethyl-3-(3-dimethylaminopropyl)-carbodiimide (EDC), and $N$-hydroxysuccinimide (NHS) were obtained from Farfield Group (Cheshire, UK). [( $p$ Cymene) $\left.\mathrm{RuCl}_{2}\right]_{2}$ dimer, quercetin, $\mathrm{Na}_{2} \mathrm{HPO}_{4}, \mathrm{CH}_{3} \mathrm{COONa}, \mathrm{KCl}$, $\mathrm{NaCl}$, Tween-20, EDTA, DTT, DMSO, quercetin, HMG-CoA, NADPH, Tris, sucrose, PMSF, TPCK, simvastatin and pravastatin were all obtained from Sigma-Aldrich (Milan, Italy). HepG2 epithelial hepatic carcinoma cells were obtained from American Type Culture Collection (ATCC, Manassas, VA). All chemicals were of the highest grade available. All other materials were obtained from commercial sources and were used as received. The Cary $1 \mathrm{E}$ UV-vis spectrophotometer was obtained from Varian (Palo Alto, CA). The IAsys plus biosensor came from Thermo Fisher Scientific (Milan, Italy). The HPLC system Gold equipped with a UV-vis detector, and HPLC column heater were obtained from Beckman Coulter S.p.A. (Milan, Italy). The Luna C18 column (5 $\mu \mathrm{m}$ particle size, $250 \times 4.6 \mathrm{~mm}$, equipped with a $5 \mathrm{~mm}$ guard column) was purchased from Phenomenex Italia (Bologna, Italy). IR spectra were recorded from 4000 to $600 \mathrm{~cm}^{-1}$ on a Perkin-Elmer Spectrum FT/IR-FIR Frontier instrument. ${ }^{1} \mathrm{H}$ and ${ }^{13} \mathrm{C}$ NMR spectra were recorded on a 400 Mercury Plus Varian instrument operating at room temperature $\left(400 \mathrm{MHz}\right.$ for ${ }^{1} \mathrm{H}$ and $100 \mathrm{MHz}$ for ${ }^{13} \mathrm{C}$ ) relative to TMS. Positive and negative ion electrospray ionization mass spectra (ESI-MS) were obtained on a Series 1100 MSI detector HP spectrometer using methanol as the mobile phase. Solutions (3 $\mathrm{mg} \mathrm{mL} \mathrm{m}^{-1}$ ) were prepared using reagent-grade methanol. Masses and intensities were compared to those calculated using IsoPro Isotopic Abundance Simulator, version 2.1.28. Melting points were recorded on a STMP3 Stuart scientific instrument and on a capillary apparatus. Samples for microanalysis were dried in vacuo to constant weight $\left(20^{\circ} \mathrm{C}\right.$, ca. 0.1 Torr $)$ and analysed on a Fisons Instruments $1108 \mathrm{CHNS}-\mathrm{O}$ elemental analyser.

\section{Bioinformatics}

Molecular docking analyses were performed on an Intel core I7/ Mac OS X 10.11-based platform using Autodock Vina software. ${ }^{16}$ The X-ray crystal structure of human HMGR (pdb entry: $3 \mathrm{CCT}^{\mathbf{2 1}}$ ) was obtained from the Protein Data Bank, ${ }^{22}$ while the threedimensional structures of quercetin and of ruthenium(II) $p$ cymene derivative thereof (Ru-Que) were built and minimized using the Avogadro software (version 1.1.0). ${ }^{23}$ Polar hydrogen atoms were added to the protein prior to any analysis. Autodock, a software performing a Lamarckian genetic algorithm to explore the binding possibilities of a ligand in a binding pocket, ${ }^{24}$ was used setting a grid of $30 \times 27 \times 23$ points around both HMG-CoA and NADPH binding sites with a grid spacing of $1 \AA$, a root-mean-square (rms) tolerance of $0.8 \AA$, and a maximum of 2500000 energy evaluations. Other parameters were set to default values. ${ }^{25}$ Autodock output files were rendered with PyMOL (Python Molecular Graphics - 2006; DeLano Scientific LLC, San Carlos, CA). PyMOL was also used to calculate the length of theoretical hydrogen bonds, measured between the hydrogen and predicted binding atom.

\section{SPR binding study}

HMGR was covalently anchored onto a carboxylate surface as described elsewhere. ${ }^{\mathbf{1 0}}$ Briefly, the sensing surface was set at $37{ }^{\circ} \mathrm{C}$, and sequentially rinsed with PBS-T (10 mM Na${ }_{2} \mathrm{HPO}_{4}$, $2.7 \mathrm{mM} \mathrm{KCl}, 138 \mathrm{mM} \mathrm{NaCl}, 0.05 \%$ (v/v) Tween-20, pH 7.4), and detergent-free PBS, prior to the activation of carboxylic groups with an equimolar EDC/NHS solution. ${ }^{26}$ HMGR (dissolved $10 \mathrm{mM} \mathrm{CH} \mathrm{CH}_{3} \mathrm{COONa}, \mathrm{pH} 5.5$ to a final concentration of 0.2 $\mathrm{mg} \mathrm{mL} \mathrm{m}^{-1}$ ) was incubated over the surface for $20 \mathrm{~min}$, and inefficiently bound enzyme was removed by PBS wash. Nonreacted carboxylic groups of the biosensor surface were deactivated with $1 \mathrm{M}$ ethanolamine. Next, either quercetin or Ru-Que was added at increasing concentrations (81 nM-3.6 $\mu \mathrm{M}$ and $81 \mathrm{nM}-2.1 \mu \mathrm{M}$, respectively), each time assessing baseline recovery prior to any further addition of the soluble ligands. If necessary, surface regeneration rate was increased without affecting its stability by $\mathrm{CH}_{3} \mathrm{COONa}$ washes at $\mathrm{pH} 5.5$, the affinity of the interaction being significantly diminished at lower $\mathrm{pH}$ conditions. Raw data were analysed with Fast Fit software V.2.03 (Fison Applied Sensor Technology - Affinity Sensors).

\section{Inhibition studies}

Inhibition of isolated HMGR. The effect of quercetin and RuQue on the enzymatic activity of HMGR was tested according to a chromatography-based method. ${ }^{19}$ In detail, the enzymatic residual activity was monitored upon 60 min pre-incubation of isolated HMGR $(0.4 \mu \mathrm{M})$ with increasing levels of single compounds. The pre-formed complex was added to $1.55 \mu \mathrm{M}$ HMG-CoA and $2.68 \mathrm{mM}$ NADPH dissolved in the activity buffer (100 mM phosphate, $1 \mathrm{mM}$ EDTA, $10 \mathrm{mM}$ DTT, and 2\% DMSO at pH 6.8), and stored for $60 \mathrm{~min}$ at $37^{\circ} \mathrm{C}$. The resulting mixture $(10 \mu \mathrm{L})$ was separated with a Phenomenex Luna C18 reversephase (RP)-HPLC column thermostatted at $26 \pm 0.1{ }^{\circ} \mathrm{C}$, monitoring both the decrease in HMG-CoA/NADPH consumption and mevalonate/NADP ${ }^{+}$production rates. Residual activities, expressed as the ratio of mevalonate levels in the presence and in the absence of a given inhibitor concentration, were derived from raw data using a standard model for reversible competitive

$$
a_{\mathrm{i}}=1-\frac{\left(\left[\mathrm{HMGR}_{\mathrm{t}}\right]+[\mathrm{I}]_{\mathrm{i}}+K_{\mathrm{i}}\left(1+\frac{\left[\mathrm{S}_{0}\right]}{K_{\mathrm{m}}}\right)\right)-\sqrt{\left.\left(\left[\mathrm{HMGR}_{\mathrm{t}}\right]+[\mathrm{I}]_{\mathrm{i}}+K_{\mathrm{i}}\left(1+\frac{\left[\mathrm{S}_{0}\right]}{K_{\mathrm{m}}}\right)\right)^{2}-4\left[\mathrm{HMGR}_{\mathrm{t}}\right] \mathrm{I}\right]_{\mathrm{i}}}}{2\left[\mathrm{HMGR}_{\mathrm{t}}\right]}
$$


inhibition: ${ }^{20}$

where $\left[\mathrm{HMGR}_{\mathrm{t}}\right]$ is the total concentration of HMGR, $[\mathrm{I}]$ is the concentration of either quercetin or Ru-Que, $\left[\mathrm{S}_{0}\right]$ is the saturating concentration of used substrate and $K_{\mathrm{m}}$ is the substrate concentration for half maximal velocity. Hydrophilic pravastatin and hydrophobic simvastatin were used as reference inhibitors of HMGR.

Inhibition of cellular HMGR. The effects of Que, Ru-Que, simvastatin and pravastatin were tested also on microsomal HMGR from human liver carcinoma HepG2 cell lines. Cells were grown in a $5 \% \mathrm{CO}_{2}$ atmosphere at $37^{\circ} \mathrm{C}$ in $100 \mathrm{~mm}$ tissue culture dishes. Growth medium was MEM supplemented with $10 \% \mathrm{FBS}, 1 \%$ sodium pyruvate, antibiotic and antimycotic. Upon confluence, cells contained in two flasks were harvested and centrifuged at $8000 \times g$ for $5 \mathrm{~min}$. Pellet was suspended in $2 \mathrm{~mL}$ of PBS and centrifuged at $10000 \times g$ for $5 \mathrm{~min}$. The obtained pellet was re-suspended in inhibition buffer (HEPES 5 $\mathrm{mM}$, sucrose $0.25 \mathrm{mM}$, PMSF $100 \mu \mathrm{M}$ and leupeptin $100 \mu \mathrm{M}$, $\mathrm{pH}$ 7.4). The cell suspension was lysed using a syringe with a 29-gauge needle. The lysate was centrifuged at $20000 \times g$ for 15 min at $4{ }^{\circ} \mathrm{C}$. The supernatant was collected and centrifuged at $100000 \times g$ for $60 \mathrm{~min}$ at $4{ }^{\circ} \mathrm{C}$. Microsomal pellet was suspended in the activity buffer. Total protein content was determined according to the method of Lowry et al. ${ }^{27}$ HMGR activity was tested in the microsomal fraction in the presence of increasing concentrations of Que (0-2 mM) Ru-Que (0-0.5 $\mathrm{mM})$ pravastatin $(0-5 \mu \mathrm{M})$ and simvastatin $(0-100 \mu \mathrm{M})$, using the same protocol used for the isolated enzyme. Prior to injection, a centrifugation step at $10000 \times g$ for 10 min was necessary to precipitate cell membranes. HMGR residual activity and inhibition constant for each inhibitory compound were calculated.

\section{Effect on cholesterol levels}

Cytoplasmic cholesterol levels in HepG2 cells upon treatment were measured to assess the effective cholesterol-lowering capacity of Ru-Que, in comparison with both the parent compound and pravastatin and simvastatin. After $4 \mathrm{~h}$ incubation at $37{ }^{\circ} \mathrm{C}$ in the presence of 5 and $50 \mu \mathrm{M}$ of each compound, cells were trypsinized, washed with PBS, and centrifuged at $8000 \times g$ for $5 \mathrm{~min}$. For each sample, cytoplasmic cholesterol concentration was measured using AmplexRed Cholesterol Assay kit. Briefly, the pellets were suspended in $40 \mu \mathrm{L}$ of $1 \times$ reaction buffer and lysed with a $29 \mathrm{G}$ syringe. The working solution, containing Amplex® Red reagent $(300 \mu \mathrm{M})$, horseradish peroxidase $\left(2 \mathrm{U} \mathrm{mL}^{-1}\right)$, cholesterol oxidase $\left(2 \mathrm{U} \mathrm{mL}^{-1}\right)$, and cholesterol esterase $\left(0.2 \mathrm{U} \mathrm{mL}^{-1}\right)$ in $1 \times$ reaction buffer was freshly prepared before each experiment. Cholesterol reference standard curve was prepared diluting cholesterol reference standard $(5.17 \mathrm{mM})$ in $1 \times$ reaction buffer. $50 \mu \mathrm{L}$ of working solution, $40 \mu \mathrm{L}$ of $1 \times$ reaction buffer and $40 \mu \mathrm{L}$ of cell lysates were placed in a 96-well plate and incubated at $37{ }^{\circ} \mathrm{C}$ for $30 \mathrm{~min}$. After $4 \mathrm{~h}$, fluorescence measurements were recorded $\left(\lambda_{\mathrm{exc}}=540 \mathrm{~nm}, \lambda_{\mathrm{em}}=590 \mathrm{~nm}\right)$ using a SpectraMax Gemini XPS microplate reader (Molecular Device, Milan - Italy).

\section{Cell viability}

Tetrazolium salt MTT (3-(4,5-dimethylthiazol-2-yl)-2,5-diphenyltetrazolium bromide) assay is based on the conversion of soluble tetrazolium into insoluble blue formazan crystals. The tetrazolium ring is cleaved only in active mitochondria, thus only in living cells. MTT concentration can be read at $570 \mathrm{~nm}$ on a scanning multiwell spectrophotometer (ELISA reader). ${ }^{28}$ MTT assay was performed on HepG2 cells treated for $24 \mathrm{~h}$ with increasing concentrations of Ru-Que $(0-100 \mu \mathrm{M})$, Que $(0-100 \mu \mathrm{M})$, pravastatin $(0-100 \mu \mathrm{M})$ and simvastatin $(0-100 \mu \mathrm{M})$ to test their toxicity (concentrations were chosen based on HMGR activity tests). An adequate number of cells were plated in a 96-well plate (5 five replicates each). Compounds were added and cells were incubated for $24 \mathrm{~h}$ at $37^{\circ} \mathrm{C}$. Culture medium containing MTT (0.5 $\mathrm{mg} \mathrm{mL}{ }^{-1}$ ) was added and left for $2 \mathrm{~h}$. After removing MTT, DMSO was added for $10 \mathrm{~min}$ and finally optical density was measured at $570 \mathrm{~nm}$ with a multiwell scanning spectrophotometer. Viability was calculated following the equation: \% viability $=[(\mathrm{OD} 570 \mathrm{~nm})$ sample/(OD $570 \mathrm{~nm})$ negative control] $\times 100$.

\section{Statistical analysis}

Results are expressed throughout as mean values \pm standard deviation of data obtained from five separate experiments. Statistical analysis was performed with one-way ANOVA, followed by the Bonferroni test using MatLab R2015b. $p$ values < 0.05 were considered statistically significant.

\section{Conclusions}

Natural products and synthetic compounds share a critical role in the development of novel pharmaceuticals. Constant improvements in synthetic methodology have provided practical access to a vast array of synthetic and semi-synthetic substances, these latter being regarded as intermediate between natural and synthetic substances.

On such a basis, we synthesized an organometallic derivative of quercetin in the effort of improving its biological activity. Computational docking analysis suggested that (differently from parent counterpart) Ru-Que derivative could accommodate within the substrate-binding portion of HMGR active site. A significant difference in the predicted binding affinity, likely attributable to the higher structural rigidity and a more favourable conformation conferred by arene-Ru complexation (and capable of preventing the access of HMG-CoA to the catalytic region) was observed.

These theoretical differences were experimentally validated both in cell-free and in cell-based assays. In detail, the inhibition of isolated HMGR by quercetin, as well as the calculated binding affinity, were strongly enhanced upon functionalization to reach a statin-like potency ( $K_{\mathrm{i}}$ was in the same nanomolar range of the hydrophobic simvastatin), the kinetic dissection of binding revealing a major contribution of dissociation events in the stabilization of the complex. A fully comparable behaviour was observed on microsomal HMGR, even if with a general 2fold decrease in inhibitory potencies for all compound tested with respect to cell-free assay. Finally and most interestingly, 
non-cytotoxic level of the Ru-Que were highly effective in lowering cytoplasmic cholesterol levels in HepG2 human hepatocarcinoma cells at $4 \mathrm{~h}$, again with an efficacy fully comparable to more cytotoxic simvastatin. Globally, the relevant enhancement to bioactive properties of quercetin induced by $\mathrm{Ru}(\mathrm{II})$ complexation represents a stimulating starting point for the development of new semi-synthetic pharmaceutical agents to be used in the treatment of hypercholesterolemia.

\section{Acknowledgements}

The authors thank the University of Camerino for financial support.

\section{References}

1 L. Bonfili, V. Cecarini, M. Amici, M. Cuccioloni, M. Angeletti, J. N. Keller and A. M. Eleuteri, FEBS J., 2008, 275, 5512-5526.

2 C. Spatafora and C. Tringali, Anti-Cancer Agents Med. Chem., 2012, 12, 902-918.

3 A. Tresserra-Rimbau, E. B. Rimm, A. Medina-Remon, M. A. Martinez-Gonzalez, R. de la Torre, D. Corella, J. Salas-Salvado, E. Gomez-Gracia, J. Lapetra, F. Aros, M. Fiol, E. Ros, L. Serra-Majem, X. Pinto, G. T. Saez, J. Basora, J. V. Sorli, J. A. Martinez, E. Vinyoles, V. RuizGutierrez, R. Estruch, R. M. Lamuela-Raventos and P. S. Investigators, Nutr., Metab. Cardiovasc. Dis., 2014, 24, 639-647.

4 N. Saint-Cricq De Gaulejac, C. Provost and N. Vivas, J. Agric. Food Chem., 1999, 47, 425-431.

5 M. Kampa, A. Hatzoglou, G. Notas, A. Damianaki, E. Bakogeorgou, C. Gemetzi, E. Kouroumalis, P. M. Martin and E. Castanas, Nutr. Cancer, 2000, 37, 223-233.

6 H. C. Li, S. Yashiki, J. Sonoda, H. Lou, S. K. Ghosh, J. J. Byrnes, C. Lema, T. Fujiyoshi, M. Karasuyama and S. Sonoda, Jpn. J. Cancer Res., 2000, 91, 34-40.

7 L. Duluc, C. Jacques, R. Soleti, F. Iacobazzi, G. Simard and R. Andriantsitohaina, Int. J. Biochem. Cell Biol., 2013, 45, 783-791.

8 S. Meguro, T. Hasumura and T. Hase, Nutr. Metab., 2013, 10, 61.

9 T. Tamura, N. Inoue, M. Ozawa, A. Shimizu-Ibuka, S. Arai, N. Abe, H. Koshino and K. Mura, Biosci., Biotechnol., Biochem., 2013, 77, 1306-1309.

10 M. Cuccioloni, M. Mozzicafreddo, M. Spina, C. N. Tran, M. Falconi, A. M. Eleuteri and M. Angeletti, J. Lipid Res., 2011, 52, 897-907.
11 T. Carbonell and E. Freire, Biochemistry, 2005, 44, 1174111748.

12 A. Corsini, F. M. Maggi and A. L. Catapano, Pharmacol. Res., 1995, 31, 9-27.

13 C. Koebnick, A. L. Garcia, P. C. Dagnelie, C. Strassner, J. Lindemans, N. Katz, C. Leitzmann and I. Hoffmann, J. Nutr., 2005, 135, 2372-2378.

14 R. Pettinari, C. Pettinari, F. Marchetti, B. W. Skelton, A. H. White, L. Bonfili, M. Cuccioloni, M. Mozzicafreddo, V. Cecarini, M. Angeletti, M. Nabissi and A. M. Eleuteri, J. Med. Chem., 2014, 57, 4532-4542.

15 L. Bonfili, R. Pettinari, M. Cuccioloni, V. Cecarini, M. Mozzicafreddo, M. Angeletti, G. Lupidi, F. Marchetti, C. Pettinari and A. M. Eleuteri, ChemMedChem, 2012, 7, 2010-2020.

16 O. Trott and A. J. Olson, J. Comput. Chem., 2010, 31, 455-461. 17 L. Tabernero, D. A. Bochar, V. W. Rodwell and C. V. Stauffacher, Proc. Natl. Acad. Sci. U. S. A., 1999, 96, 7167-7171.

18 M. Mozzicafreddo, M. Cuccioloni, L. Bonfili, A. M. Eleuteri, E. Fioretti and M. Angeletti, Biochim. Biophys. Acta, 2008, 1784, 995-1001.

19 M. Mozzicafreddo, M. Cuccioloni, A. M. Eleuteri and M. Angeletti, J. Lipid Res., 2010, 51, 2460-2463.

20 J. G. Bieth, Some Kinetic Consequences of the Tight Binding of Protein-Proteinase-Inhibitors to Proteolytic Enzymes and Their Application to the Determination of Dissociation Constants, Springer-Verlag, Berlin, 1974.

21 R. W. Sarver, E. Bills, G. Bolton, L. D. Bratton, N. L. Caspers, J. B. Dunbar, M. S. Harris, R. H. Hutchings, R. M. Kennedy, S. D. Larsen, A. Pavlovsky, J. A. Pfefferkorn and G. Bainbridge, J. Med. Chem., 2008, 51, 3804-3813.

22 H. M. Berman, J. Westbrook, Z. Feng, G. Gilliland, T. N. Bhat, H. Weissig, I. N. Shindyalov and P. E. Bourne, Nucleic Acids Res., 2000, 28, 235-242.

23 M. D. Hanwell, D. E. Curtis, D. C. Lonie, T. Vandermeersch, E. Zurek and G. R. Hutchison, J. Cheminf., 2012, 4, 17.

24 G. M. Morris, R. Huey, W. Lindstrom, M. F. Sanner, R. K. Belew, D. S. Goodsell and A. J. Olson, J. Comput. Chem., 2009, 30, 2785-2791.

25 M. Mozzicafreddo, M. Cuccioloni, V. Cecarini, A. M. Eleuteri and M. Angeletti, J. Chem. Inf. Model., 2009, 49, 401-409.

26 P. R. Edwards, P. A. Lowe and R. J. Leatherbarrow, J. Mol. Recognit., 1997, 10, 128-134.

27 O. H. Lowry, N. J. Rosebrough, A. L. Farr and R. J. Randall, J. Biol. Chem., 1951, 193, 265-275.

28 T. Mosmann, J. Immunol. Methods, 1983, 65, 55-63. 